\title{
Extending Information On Museum Artefacts Through Augmented Reality: Indonesian National Museum Case
}

\author{
Bayu Prakoso Dirgantoro \\ BNSD - Graphic Design \\ Bina Nusantara University \\ Jakarta, Indonesia
}

\author{
Jude Joseph Lamug Martinez \\ Computer Science Program \\ Bina Nusantara University \\ Jakarta, Indonesia
}

\begin{abstract}
Jakarta has 62 well-maintained museums but most are still conventional in the way that they mostly display objects or collections with accompanying written information and interactive media is still very limited.[1] In Indonesia, museum curators and managers need to be more creative in presenting objects and information to increase the number of visitors [2].The difficulty of luring visitors to museums has even became a national issue and problem:[1] the Indonesian government considers it as a matter that needs to be addressed. [3, 4] In 2010, the Association of Museums in Indonesia (AMI) and the Ministry of Tourism and Creative Economy declared it the Year of Visiting the Museum [5] as part of the National Movement to Love Museums, which lasted until 2014 [1]. The strategic efforts from the Ministry of Tourism and Creative Economy were then followed up with the introduction of national programs such as Revitalizing Indonesian Museum [5]. Museums should be a place to enhance the learning experience, sharing knowledge, as well as a place to study and conduct research [5]. Here, the museum is required not only as a means of public learning, but must also be able to support the development of study centers in universities [5]. Therefore, adding interactive media using Augmented Reality to Indonesian museums will increase the interest in learning about the local culture and heritage of Indonesia among the Indonesian population, especially students.
\end{abstract}

Keywords: interactive media, augmented reality, museum, learning experience, culture and heritage

\section{INTRODUCTION}

The development of new technologies is creating new improvements in all sectors of the industry, museums are not an exception to such trend. The digital era has transformed museum business models into virtual museums utilizing the web and mobile technologies. Museums started digitizing their collections not only for the sake of preserving the cultural heritage, but also to make the information content accessible to the wider public in a manner that is attractive and engaging. Emerging technologies, such as Virtual Reality (VR), Augmented Reality (AR) and the World Wide Web (WWW) are widely used to create virtual museum exhibitions both in a museum environment through informative kiosks, mobile applications and the web. Visitors are having a new learning experience through various platforms and channels.

In Indonesia, specifically in Jakarta, it is unfortunate that the development of museums is very far from expectations. A good example is National Monument (Monas) as one of the icons of this capital city, the number of visitors for the past two (2) years has greatly decreased from from $1,515,844$ to $1,369,472$ [6]. This museum itself has not been innovated well in terms of technology. Whereas other cities, for example Yogyakarta; some of its museums have already supported by the presence of Augmented Reality. UGM Museum had conducted a research and managed to improve the number of visitors through an Augmented Reality application. With the touch of technology in delivering the information; the old-fashioned impression at the museum could be eliminated. Furthermore, the young people who are more habitual with technology will be more interested to learn in the museum [7]. The museum holds a very important role towards strengthening the identity of the community including the surrounding communities. The concern for the identity of the community or nation in the developed world to the development of culture and their environment is reflected in the interest of people to visit museums. The growing public enthusiasm can be developed if there is a process of creativity by the curators and managers of the museum, especially on the programs offered to the community. While the public sees the museum as a repository of ancient objects, as a place to obtain historical information or, as well as a place for entertainment, It can even be said to be most museums in Indonesia is now more representative of the formal impression like office buildings were not only dirty, dull and eerie, but also less visible impression has appeal to invite the interest of the public or tourists to visit it. This serves a a pressing challenge for the researchers to enhance and extend the information on museum artefacts to deliver content virtually, create a platform for understanding digital artefacts wherein these digital knowledges provide new identities for its physical counterpart, conserve Indonesian cultural artefacts thru digitization by creating an application as a proof-of-concept, giving a new facility for interactivity which is fun and at the same time educational.

\section{PROBLEM ANALYSIS}

To understand the need of new media in Museum, the researchers visited various sites which include Museum Nasional (also known as Museum Gajah), Museum Bank 
Indonesia, and Museum Perumusan Naskah Proklamasi. The three museums were chosen based on location, popularity, and historical content that might be relevant to be updated using current technology.

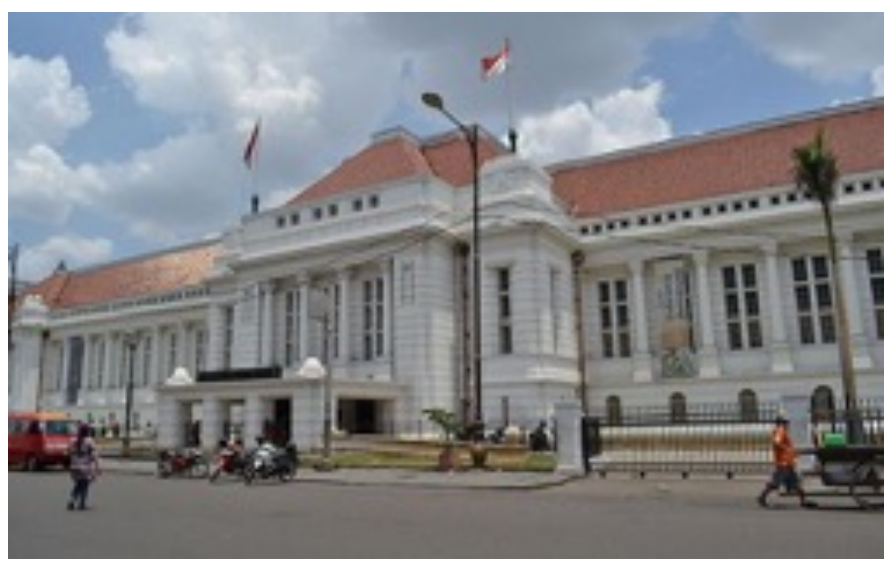

Fig. 1 Museum Bank Indonesia

The first museum visited was Museum Bank Indonesia located on Jalan Pintu Besar Utara no. 3, West Jakarta. Focusing on the role of Bank Indonesia and its monetary policy before the colonial era until the modern era, it offers one of the best presentations in displaying various objects.

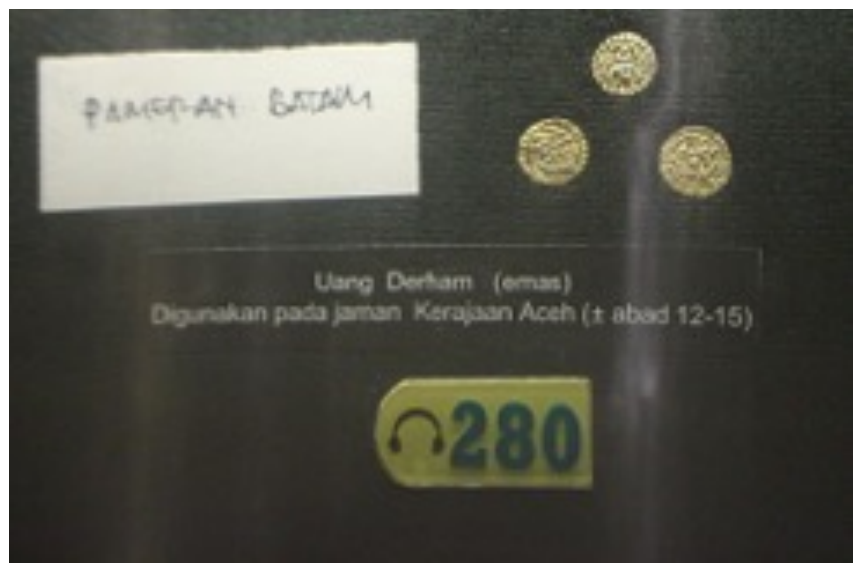

Fig. 2 Headphone icon example

The role of Multimedia is prominent in this Museum. The visitors may borrow an iPod to hear additional information throughout the collections. Most collections with a headphone icon can access their iPod to hear an in-depth information for that particular piece.

Another example of Multimedia usage in this museum is the use of touch screen monitors to simulate various monetary condition in Indonesia in a form of animation, video, even interactive media.

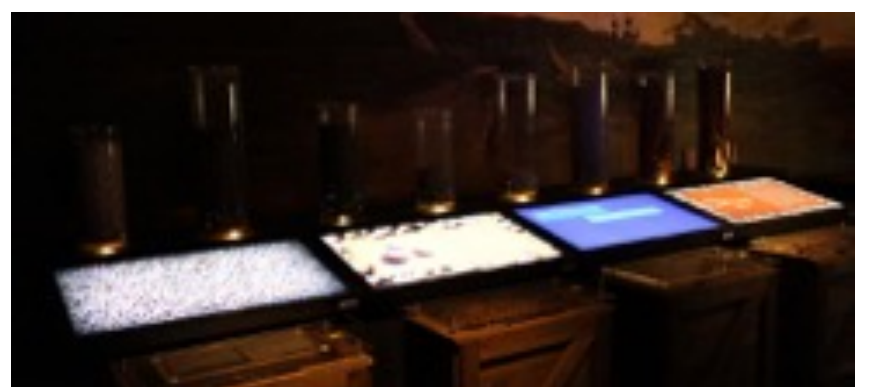

Fig. 3 Touch screen monitors

Each multimedia device is a complement to the collection, adding additional value for the visitor. The information laid out clear and focused for the selected object / display. Some video displays in a form of new media art and while visually looked good, the audio supported somehow lacking and does not represent the collection depicted in the area. Overall, Museum Bank Indonesia sets a standard in Multimedia aspect to enhance the visitor's experience.

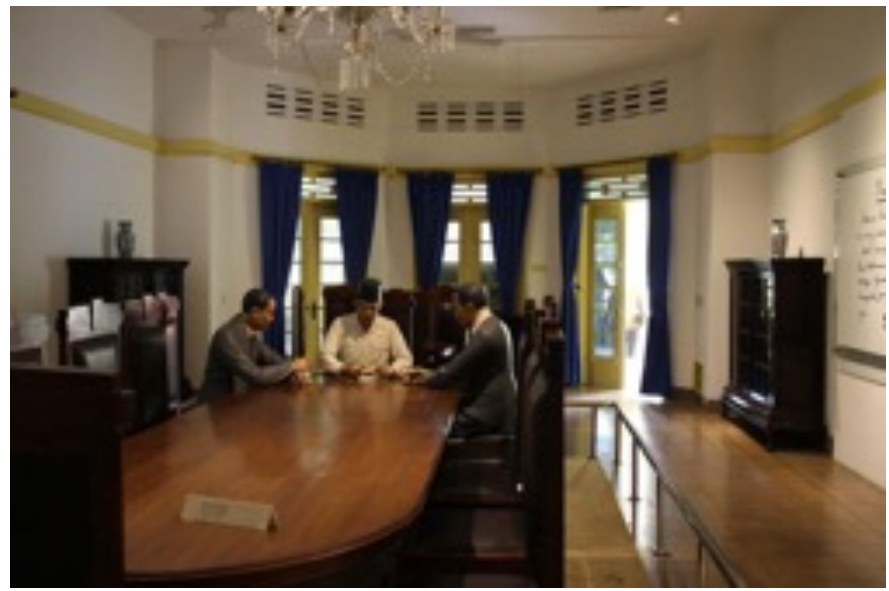

Fig. 4 Museum Perumusan Naskah Proklamasi

The second museum the researchers visited is Museum Perumusan Naskah Proklamasi on Jalan Imam Bonjol. The site is quite unique because the building used is still designed in a form of a colonial building. the Museum offers a variety documentation during the Indonesian Independent era. Museum Perumusan Naskah Proklamasi is one the traditional type of museum in Jakarta. Diorama and Printed Information for each collection is visible throughout each thematic room. Each display provides information, some are very detailed and well curated, and some are only a base description of an object related to the display. The Diorama is depicted accurately based on the history and well documented by several photographs accompanied.

The second museum the researchers visited is Museum Perumusan Naskah Proklamasi on Jalan Imam Bonjol. The site is quite unique because the building used is still designed in a form of a colonial building. the Museum offers a variety documentation during the Indonesian Independent era. Museum Perumusan Naskah Proklamasi is one the traditional type of museum in Jakarta. Diorama and Printed Information for each collection is visible throughout each thematic room. Each display provides information, some are very detailed and well 
curated, and some are only a base description of an object related to the display. The Diorama is depicted accurately based on the history and well documented by several photograph accompanied.

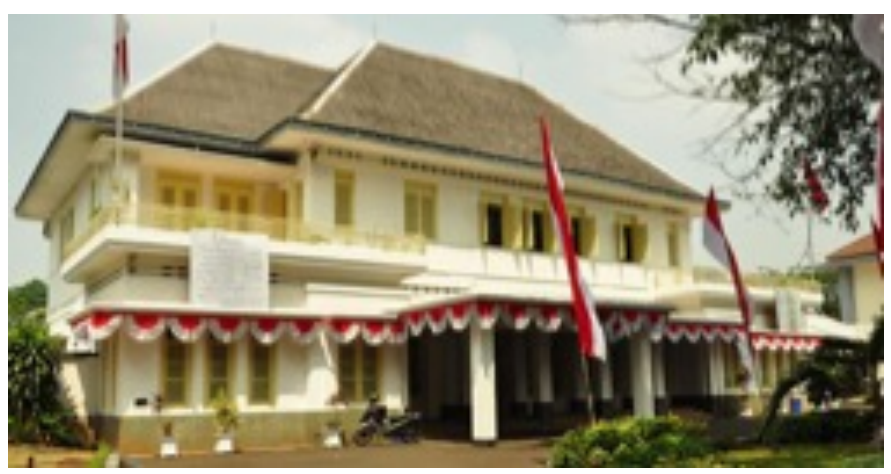

Fig. 5 Diorama Room

Part of the collections are displayed as a poster with a ton of text as their information. This requires a lot of reading in a room that is not suitable for a long period of reading. The researchers could not check at the only multimedia displayed in the museum due to out of order.

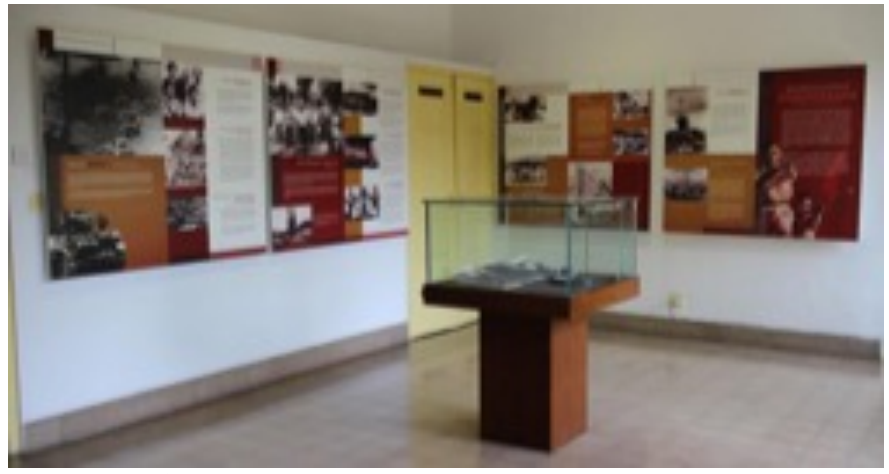

Fig. 6 Display room

The atmosphere for this museum is quite empty and static, while the content is very interesting and focused. The information laid out is very basic. The researchers found a potential to enhance the museum for the project.

The Last Museum visited for this research is Museum Nasional. Located in the very heart of Jakarta just across of Monumen Nasional, one of the famous landmarks in Jakarta. The site is chosen due to its popularity and the wide variety of content including archeological, historical, ethnological, and geographical aspect of Indonesia.

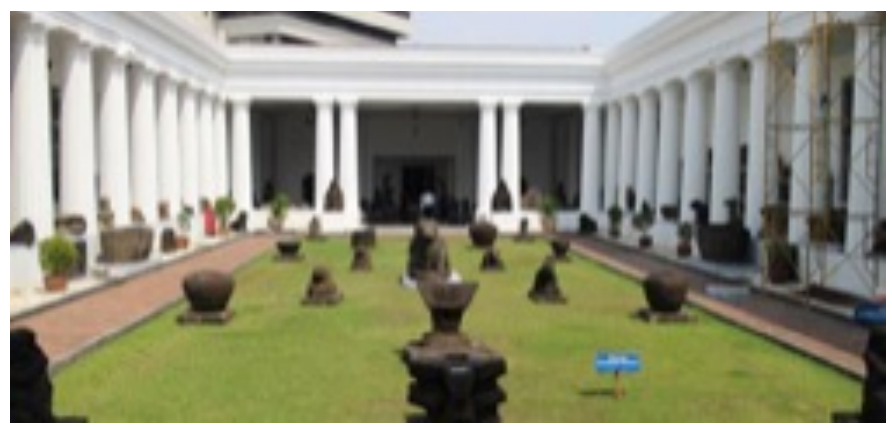

Fig. 7 Museum Nasional

Divided into 6 areas in the old wing, each section packed with various artefacts across the archipelago. The researchers focused on the ethnography collection due to the variety, size and type of object displayed. The Museum provides a static experience with most artefacts having very minimal information. As a traditional museum, the ethnography section is one of most popular area. With artefacts from across Indonesia, this section has a lot to offer and the objects are quite interesting as well.

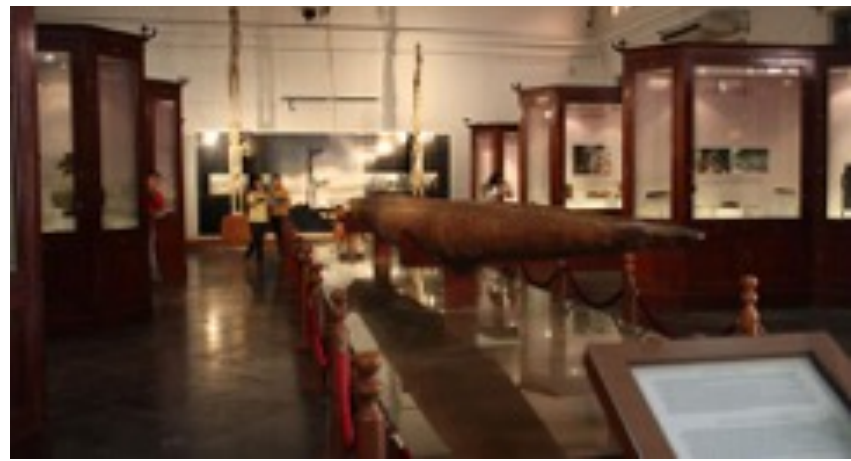

Fig. 8 Ethnography Section

Museum Nasional is one of the most famous museums in Jakarta. The museum is one of the destinations for school trip, meaning it always have a constant visitor. Like other Museums, Museum Nasional also provides a tour guide explaining each artefact in the museum. Small - Medium Sized Collections are put in the glass display on the side of the room while the bigger artefact are shown in the middle of the room with detailed information. One of the strengths of Museum Nasional is the number of collections with 140,000 based on the data in the year 2006, making it the most complete museum in Indonesia, although only one third of the collection is displayed for public.

To conclude the initial research of the museums, the researchers found that Museum Bank Indonesia has the most dynamic and active experience for visitors. Using various contraptions and technology to display their collection, Museum Bank Indonesia can be considered as one of the good examples on how to engage the audience using current technology. Both Museum Nasional and Museum Perumusan Naskah Proklamasi lacks the ability to engage the visitor despite both have an interesting story to tell. Museum Perumusan Naskah Proklamasi has a strong aspect in telling the story, yet the documentation only displayed by static diorama and posters. Museum Nasional has the largest library and an interesting artefact in terms of 
shapes but most of the visitor only skim through the cllection. After the Initial visit to the three (3) museums, the researchers decided to work on part of the object displayed in Museum Nasional due to its popularity with the lack of interactivity / engagement with the visitor.

\section{MUSEUM TECHNOLOGIES}

Museums being one of the tourism assets in each country have implemented technologies in the operational system. Here are several of them: electronic display, documentary film, digital learning, 3D printing display, digitization, social media, and many more. Electronic displays are used as screen projectors that are directed to the floor or walls. Documentary about the museum in the form of film and then shown to the visitors through theatre or projectors. Digital learning with the use of games containing information about museum objects, including augmented reality concept [12].

\subsection{Digital Learning}

By definition, digital learning means, "learning facilitated by technology that gives student some element of control over time, place, path/ or pace" [13]. Digital learning includes the digital content material, which delivered to the user through the electronic devices. Ipad, smartphones, laptop, and other gadgets are counted as the media to deliver the content through the Internet access. Not only from a simple pdf file or PowerPoint presentation, but an innovative way to deliver the content is necessary to do the digital learning. Same thing happens for the museum [13].

\subsection{D Printing Display}

Museum needs to get another creative way to attract the guests for learning. 3D printing is one method to do that. By printing the computer data into a real physical object, museum could inspire a creative innovation in delivering information [14].

\subsection{Documentary Film}

Nonfictional film proposed to document some aspect of reality, mainly for maintaining an ancient documentation. This method also counted as a technology that is used by the museum to keep their historical data [15].

However, not all museums have implemented these technologies, such as Museums in Jakarta. In fact, it is undeniable that technologies provide a significant impact in the development of the museum.

\subsection{Social Media}

Nowadays, social media is one of the most frequently used media to disseminate information. Based on its definition, social media itself means websites and applications where the users are enabled to create and sharing content into social networking [16]. Social Media forms a big part of communication these days. Recent surveys were conducted on the US and said two of five American spends more time on online socializing rather than normal communication [17]. Therefore, it is not surprisingly if social media is also entering the part of marketing tool. Here are some examples of social media commonly used:
Facebook, Twitter, Pinterest, Linked- In, Instagram, Google Plus, and many more [20].

\subsection{Augmented Reality}

Augmented Reality is a technology where real world objects and digital data are combined together. Most AR research processes a live video image digitally then add computer-digital data. The data could be in form of graphics, sound, video, image, $3 \mathrm{~d}$ object, etc. As long as it is a digital computer data, it still counted as Augmented Reality concept [19].

In other words, AR combines the computer vision with the computer graphics. The vision of AR includes marker detection, feature detection, motion detection, image analysis, and gesture recognition. While for computer graphics' examples are photo rendering and animations [19].

In 1997, Ronald Azuma made an explanation about Augmented Reality. He says there are 3 main components of Augmented Reality itself, which are [22]:

1. Combine real and virtual

2. Interactive in real- time

3. Registered in $3 \mathrm{D}$

A prominent opinion comes from one of Jakarta's citizens itself. He wrote a suggestion letter to Culture and Tourism Officer in Jakarta. In his letter, he asks the officer to bring IT technology in tourism objects in Jakarta, such as tourist information service and museum technologies like others country had. He said the lack of technology contribution became the one that interrupts the development process of tourism in Jakarta. Jakarta as a capital city of Indonesia should supports its tourism industrial, including their Museums [21].

Another opinion comes from the foreigner who got interviewed towards Museum in Jakarta. In his answer, he mentioned that Jakarta museum lack of elements of modernity. He mentioned there are no elegant cafes, bookstores or public archives like others Museum normally had. He also said that Jakarta museum is lack of vision and creativity. Even there is a vision or creativity, funding becomes the most problems to carry it out [22]. As Ardiwidjaja (2008) mentions that the most Museum problems in the country are the gap between intricacy of its function and human resource professionalism, lack in using the technology, and way too far from modern perception [23]. These issues really had a significant impact to the number of its visitors. Like already mentioned on Chapter 1, a university in Jogja conducted a research by implementing technology (Augmented Reality) to the Museum and successfully achieves around 500 visitors. On the other hand, Jakarta museums still have not showing any improvement in using the technology.

To conclude, tourism industrial in Jakarta, especially museum has not been supported enough by the technology. Jakarta should start to use technologies to support their Museum as the part of its tourism asset. The objective of the author becomes to develop a mobile-device application using Augmented Reality, which will be delivered to the Museum as a tourism object. Moreover, author also realized the great number of social media users in Indonesia, such Facebook users that become the fourth largest in the world [24] and Twitter users 
in Jakarta as the biggest in the world [25]. This fact inspired user to combine the Augmented Reality technology with the social media as well in order to spread the Museum information to the society.

\section{SOLUTION DESIGN}

Silverstone states that 'museums are in many respects like other contemporary media. They entertain and inform; they tell stories and construct arguments; they aim to please and to educate; they define, consciously or unconsciously; effectively or ineffectively, an agenda; they translate the otherwise unfamiliar and inaccessible into the familiar and accessible [8]. Advances in technology has paved way for the use of tools and customized interfaces for generating digital content and interactivity for real world objects [9] and could be integrated into interactive AR interfaces [10], thus creating an approach which is closer to reality and enhancing the experience of visitors in the museum.

As such, the researchers created a mobile application using AR, using an actual artifact (Congklak), the object is digitized and overplayed upon video frames and captured by the mobile phones' camera, giving the users an impression that the virtual artifact actually exist in the environment. Additional functionality and data is also added such that the user could learn about the artifact and interactively play with it in the process.

\subsection{Congklak Augmented Reality Design Process}

Congklak is a traditional game that is known by various names throughout Indonesia, it is a game played on a wooden boat-shaped block with two rows of seven circular holes and two large holes at both ends called "home". The game begins with seven game pieces (shells, marbles, pebbles or seeds) in each hole except "homes" which remain empty. Congklak requires two players. Each player controls the seven holes on his side of the board and owns the "home" to his left. The goal is to accumulate as many pieces in your own "home". On a turn, a player removes all pieces from one of the seven holes on his side. He then distributes them clockwise; one in each hole to the left of this hole; in a process called sowing. Sowing skips an opponent's "home" but not a player's own "home". If the last piece falls into an occupied hole then all the pieces are removed from that hole, and are sown in the same way (clockwise from that hole) in another round. This player's (current) turn ends when the last piece falls into an empty hole on the opponent's side. If the last piece sown falls into a player's own "home" then the player earns another turn, which can begin at any of the seven holes on his side. If the last piece sown falls into an empty hole on his side then the player captures all the pieces in the hole directly across from this one, on the opponent's side and put them (plus the last piece sown) in his own "home". If the opposing hole is empty, no pieces are captured. The other player chooses which hole he wishes to start from, removes the pieces and sows them - one in each hole, clockwise from that chosen hole. If a player has no pieces on his side of the board when it is his turn, then he must pass. The game ends when no pieces are left in any hole on both sides of the board. The players now count the number of pieces in their own "home" and see who has won.

Congklak is one of the objects displayed in the Museum Nasional. Originally from Java, it is an interesting artifact because not only it is still available in the market, but also available in many forms including digital version. Congklak is a popular traditional toy, yet the object lacks information in the museum.

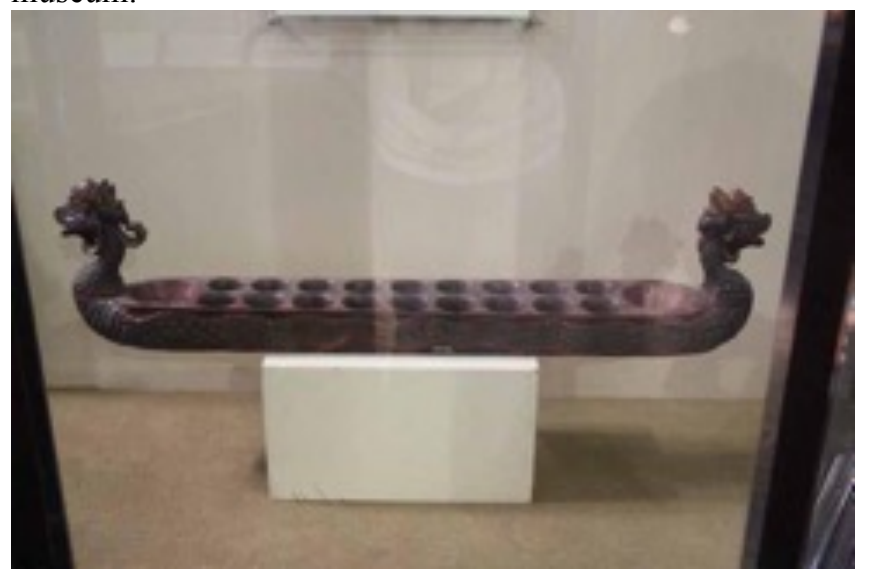

Fig. 9 Congklak in the Museum Nasional

The purpose of the application is to introduce Congklak to the younger audience and foreign visitors of the Museum. The application needs to have sufficient information regarding the Congklak, and an ample amount of interactivity to support the artifact's information.

The purpose of the application is to introduce Congklak to the younger audience and foreign visitors of the Museum. The application needs to have sufficient information regarding the Congklak, and an ample amount of interactivity to support the artifact's information.

\subsubsection{Application requirements}

The Device used is Android tablet (Landscape). The Marker is an actual Congklak (simulated for Museum Nasional) User can interact to see information of Congklak. User can play / simulate how to use Congklak

\subsubsection{Initial Sketches}

The researchers started by understanding how the Congklak works and looking at various design aspects based on the project requirement. By putting the entire interface on the bottom screen, the actual object can still be projected nicely and serve as a focal point. 

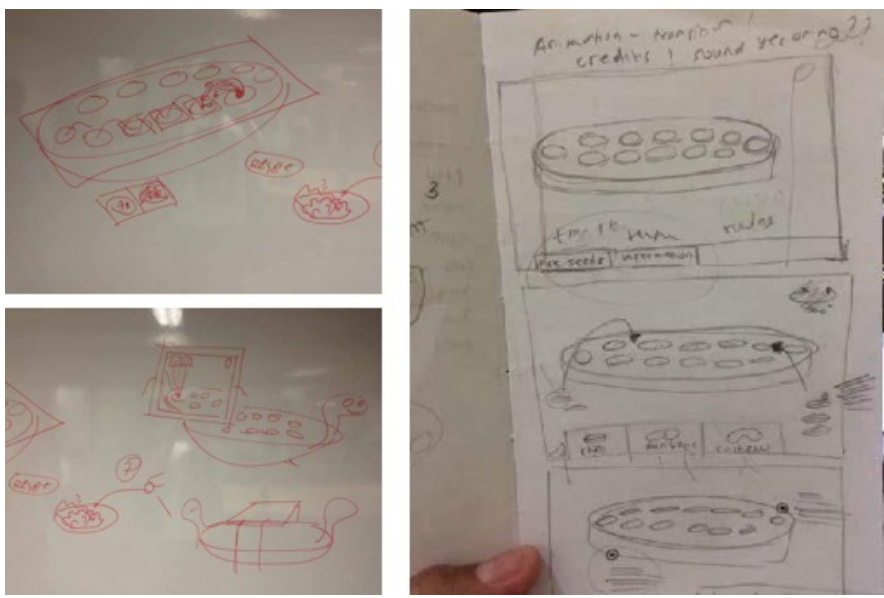

Fig. 10 Sketches of User Interface

\subsubsection{Initial User Interface}

Once the Sketches are approved, the researchers then simulate the design using various design software. The idea is to see whether the initial sketches are applicable in a form of a visual interface.

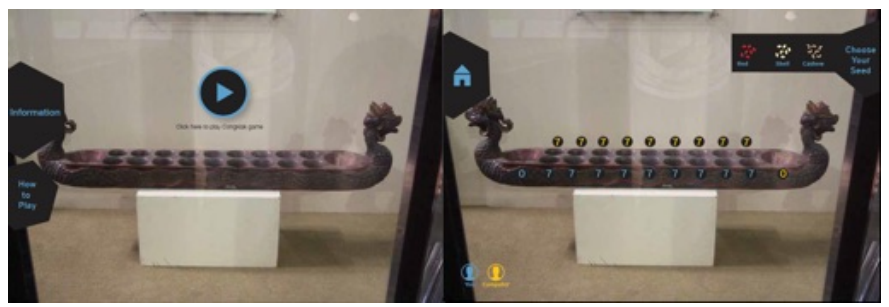

Fig. 11 Initial UI

Using the actual Congklak as the focal points, the researchers then decided to use the left and right part of the device as their menu area, while keeping the middle part as clean as possible. One aspect of the project is to be able to play/ simulate the game of Congklak, thus the researchers provide a game using augmented reality. The idea is to combine traditional play using current technology.

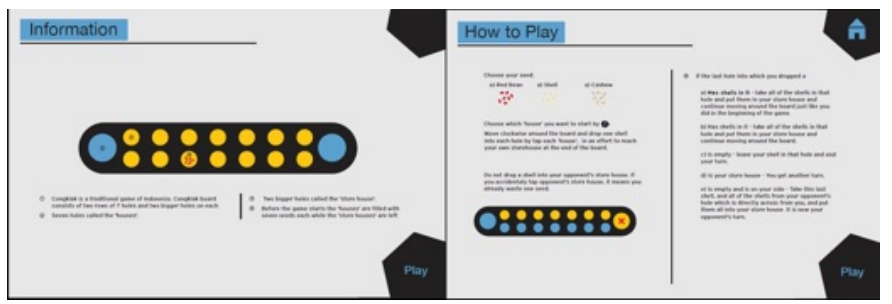

Fig. 12 Menu Interface

Once the UI is finalized, the researcher then implemented the design to the actual device and starts the playtesting to see whether the interface is working as intended

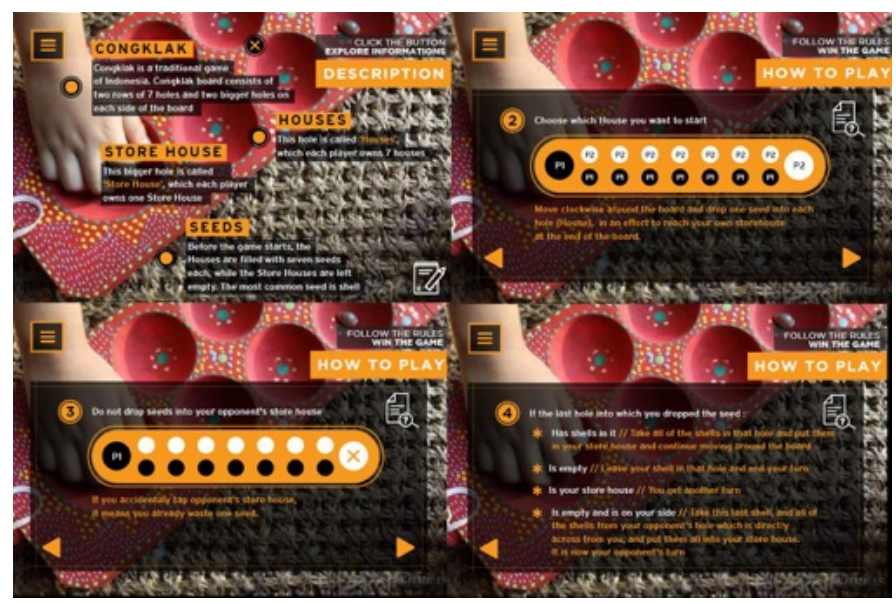

Fig. 13 Menu Interface

\section{CONCLUSION}

Museums should be a place to enhance the learning experience, sharing knowledge, as well as a place to study and conduct research [5]. Here, the museum is required not only as a means of public learning, but must also be able to support the development of study centers in universities [5]. Therefore, adding interactive media to Indonesian museums will increase the interest in learning about the local culture and heritage of Indonesia among the Indonesian population, especially students. With the use of an imaging technology such as Augmented Reality (AR) and handheld devices such as phones, phablets and tablets, museums can explore a lot of possibilities not just in digitizing data but the enhancement of the actual artifact to be interactive. Using this new technology, visitors engage in a new and unique learning experience, not just in getting but also sharing information and being able to interact with the displayed content and have an entertaining and educational experience. This also enhances the use of ICT to the museums in Indonesia with $3 \mathrm{D}$ technologies and hopefully a solution to enhance the learning experience and increase the interest of the youth learning about Indonesian culture. This leads to an enjoyable and productive experience that draws the user into involvement and participation and most likely help the promotion of actual museums.

\section{REFERENCES}

Marsanto, K. "Revalitalisasi Museum, memecah persoalan museum di Indonesia", 2013.2 [Online]. Available: http://www.antarajatim.net/lihat/berita/106728/tingkat-kunjunganmuseum-di-indonesia-rendah [Accessed: March 2015].

[2] Elyda, C. "Jakarta Needs More Interactive Museums", 2013. [Online]. Available: http://www.thejakartapost.com/news/2013/05/19/jakartaneeds-more-interactive-museums.html. [Accessed: March 2015].

[3] Marsanto, K. "Menyoal Tahun Kunjungan Museum”, 2010. [Online]. Available:

http://nasional.kompas.com/read/2010/03/03/15205585/Menyoal.Tahu n.Kunjungan.Museum. [Accessed: March 2015].

[4] Satrya, D. "Museum Week 2013: Bringing museums to modern society", 2013. [Online]. Available: http://www.thejakartapost.com/news/2013/09/07/museum-week- 
2013-bringing-museums-modern-society.html. [Accessed: March 2015].

Marsanto, K. "Revalitalisasi Museum, memecah persoalan museum di Indonesia", 2012. [Online]. Available: http://iidmarsanto.wordpress.com/2012/08/29/revitalisasi-museummemecah-persoalan-museum-di-indonesia/ [Accessed: March 2015].

[6] Kusaeni, M. P. (2014, February 12). Jumlah pengunjung Monas menurun. (U. T. Ratomo, Editor) Retrieved January 20, 2015, from Jumlah pengunjung Monas menurun - ANTARA News: http://www.antaranews.com/berita/418642/jumlahpengunjung-monasmenurun

[7] Razak, A. H. (2013, November 18). Sentuhan Teknologi Bikin Museum Menarik Lho. (M. Herawati, Editor) Retrieved February 20, 2015, from Harian Jogja :Sentuhan Teknologi Bikin Museum Menarik Lho - museum sentuhan teknologi museum - Jogjapolitan: http://www.harianjogja.com/baca/2013/11/18/sentuhanteknologibikin-museum-menarik-lho-466531

[8] R. Silverstone, The medium is the museum, in: R. Miles, L. Zavala (Eds.), Towards the Museum of the Future, Routledge, London/New York, 1994,pp. 161-176.

[9] M. Bergamasco, A. Frisoli, F. Barbagli, Haptics Technologies and Cultural Heritage Applications, in: S. Kawada (Ed.), IEEE Proceedings of the CA Conference 2002, Geneva, Switzerland, June 2002, IEEE Computer Society Press, 2002, pp. 25-32.

[10] F. Liarokapis, S. Sylaiou, A. Basu, N. Mourkoussis, M. White, P.F. Lister, An interactive visualisation interface for virtual museums, in: K. Cain, Y. Chrysanthou, F. Niccolucci, N. Silberman (Eds.), Proceedings of the VAST 2004 Conference, Belgium, EPOCH Publication, Belgium, 2004, pp. 47-56.

[11] Museums Association. (n.d.). Technology and digital | Museums Association.Retrieved January 6, 2015, from Technology and digital | Museums Association: http://www.museumsassociation.org/museumpractice/technology-anddigital

[12] Museums Association. (n.d.). Technology and digital | Museums Association. Retrieved January 6, 2015, from Technology and digital | Museums Association: http://www.museumsassociation.org/museumpractice/technology-and-digital

[13] The Governor's Office of Student Achievement. (n.d.). What is Digital Learning? Retrieved February 20, 2015, from What is Digital Learning?: https://gosa.georgia.gov/what-digital-learning

[14] Science Museum. (n.d.). 3D: Printing the Future. Retrieved February 20, 2015, from 3D: Printing the Future: http://www.sciencemuseum.org.uk/visitmuseum/plan_your_visit/exhi bitions/3d printing the future.aspx

[15] Wikipedia. (n.d.). Documentary Film. Retrieved February 20, 2015, from Documentary Film: http://en.wikipedia.org/wiki/_Documentary_film
[16] Oxford Dictionaries. (n.d.). Retrieved 1 8, 2015, from social media: definition of social media in Oxford dictionary (British \&amp; World English): http://www.oxforddictionaries.com/definition/english/social$\underline{\text { media }}$

[17] Five Functions Of Effective Social Marketing Strategy. (2012, 9 12). Retrieved 1 8, 2015, from Five Functions Of Effective Social Marketing Strategy: http://www.rackspace.com/blog/social-marketing-strategy/

[18] Top 15 Most Popular Social Networking Sites | January 2015. (n.d.). Retrieved 1 8, 2015, from Top 15 Most Popular Social Networking Sites | January 2015: http://www.ebizmba.com/articles/socialnetworking-websites

[19] Siltanen, S. (2012). Theory and applications of marker-based augmented reality. VTT, Technical Research Centre of Finland . Finland: JULKAISIJA UTGIVARE.

[20] Azuma, R. (1997). Presence : Teleporators and Virtual Environments (Vol. 6).

[21] Suharjanto, H. (2013, July 2). Respon Opini Publik\&nbsp;\&bull;\&nbsp;Usulan Pariwisata | Judul. Retrieved July 15, 2014, from Opini Publik Masyarakat Jakarta: http://prov.jakarta.go.id/opinipublik/aspirasi/2013/07/usulanpariwisata

[22] Felix, A. (2010, February 22). Katolik - View topic - Pendapat orang asing tentang Jakarta - Ekaristi. Retrieved July 15, 2014, from Ekaristi dot org: http://www.ekaristi.org/forum/viewtopic.php?t=7858\&sid=ce6824aa0 a6b1a8bc7df93ec3ca6a37a

[23] Jakarta Post. (2013, September 7). Museum Week 2013: Bringing museums to modern society | The Jakarta Post. Retrieved January 13, 2015, from Museum Week 2013: Bringing museums to modern society | The Jakarta Post: http://www.thejakartapost.com/news/2013/09/07/museum-week2013-bringing-museums-modern-society.html

[24] Okezone. (2014, September 22). Indonesia Pengguna Facebook Keempat Terbesar di Dunia. Retrieved January 12, 2015, from Indonesia Pengguna Facebook Keempat Terbesar di Dunia: http://techno.okezone.com/read/2014/09/22/55/1042737/indonesiapengguna-facebook-keempat-terbesar-di-dunia

[25] Lazada. (n.d.). Jakarta: Kota Dengan Twitter Teraktif di Dunia! . Retrieved January 13, 2015, from Jakarta: Kota Dengan Twitter Teraktif di Dunia!: http://blog.lazada.co.id/jakarta-kota-dengan-twitterteraktif-di-dunia/

[26]"Breaking the fourth wall in human-computer interaction: Really talking to each other",The Conversation, 2016. [Online]. Available: $\mathrm{http}: / /$ theconversation.com/breaking-the-fourth-wall-in-humancomputer-interaction-really-talking-to-each-other-62413. [Accessed: 14- Mar- 2016]. 